\title{
Seasonal Incidence of Major Insect-Pests on Blackgram, Vigna mungo (Linn.) and Its Correlation with Weather Parameters
}

\author{
Mun Mun Mohapatra*, D.C. Singh, P.K. Gupta, U. Chandra, \\ B. Patro and S.D. Mohapatra
}

Department of Entomology, College of Agriculture, Narendra Deva University of Agriculture and Technology, Faizabad 224229, Uttar Pradesh, India

*Corresponding author

\section{A B S T R A C T}

Keywords

Black gram, Major insect-pests, Seasonal incidence, Weather parameters

Article Info

Accepted: 28 May 2018 Available Online: 10 June 2018
Insect-pests with biotic and abiotic factors play a major role in low production and productivity of black gram in India. The insect-pests like white fly, Bemisia tabaci (Genn.), jassid, Empoasca kerri Pruthi, bihar hairy caterpillar, Spilosoma obliqua Walker and tobacco caterpillar, Spodoptera litura (F.) were recorded as major pests. The high population of 18.50 white flies/cage/plant, 36.80jassid/cage/plant, 12.60bihar hairy caterpillar/plant and 10.40tabacco caterpillar/plant were observed during $39^{\text {th }}$ standard week. Temperature (maximum \& minimum) and rainfall showed non-significant positive correlation and relative humidity showed non- significant negative with the population of white fly, jassids and bihar hairy caterpillar. The highest population of cocccinellids 2.00Coccinella septempunctata L. adult/plant and 1.20 Cheilomenes sexmaculata (F.) adult/plant were observed during $41^{\text {th }} \& 39^{\text {th }}$ standard week respectively. The maximum temperature showed non-significant positive correlation where as minimum temperature and rainfall had non-significant negative correlation while relative humidity had significant negative correlation with the population of coccinellids.

\section{Introduction}

Black gram, Vigna mungo (Linn.), FamilyLeguminosae popularly known as urd bean or mash kalai or black bean is native of India and the fourth important pulse crop with high nutritive value (Singh, 2004). Uttar Pradesh is the most agriculturally important state in India with respect to staple food production. Black gram is a prominent rainy and summer season pulse crop with area $88,000 \mathrm{ha}$, production
55.2 thousand MT and productivity $523 \mathrm{~kg} / \mathrm{ha}$ (Anonymous, 2016). In India the area, production and productivity of urdbean are 32.15 lac ha, 17.66 lac tonnes and $549 \mathrm{~kg} / \mathrm{ha}$, respectively (Khajuria et al, 2015). Black gram or Urdbean, Vigna mungo (Linn.) contributes $10 \%$ of national pulses production, is rich source of protein and carbohydrates (Ali and Gupta, 2012). On an average, 2.5 to 3.0 million tonnes of pulses are lost annually due to pest problems (Rabindra et al., 2004). 
The annual yield loss due to the insect pests has been estimated at about 30 per cent in Urd bean and Mung bean. The major insect pests which plays most important role in economic losses of black gram are white fly, Bemisia tabaci (Genn.), jassid, Empoasca kerri Pruthi, bihar hairy caterpillar, Spilosoma obliqua Walker and tobacco caterpillar, Spodoptera litura (F.).

The present investigation was carried out to know the seasonal incidence of insect pests on black gram Vigna mungo (Linn.) and their relationship with abiotic factors.

\section{Materials and Methods}

The black gram (NDU-1) crop was grown in plots having size $5 \times 4 \mathrm{~m}^{2}$ with spacing of $30 \times 10 \mathrm{~cm}$ at the Students' Instructional Farm, Narendra Dev University of Agriculture and Technology, Faizabad, Uttar Pradesh. The experimental site falls under sub-tropical climatic zone of Indo-Gangtic plains and situated at $26.47^{\circ} \mathrm{N}$ latitude and $82.12^{\circ} \mathrm{E}$ longitudes at an altitude of 113 meters from mean sea level. The weather conditions during the period of investigation is characterized by the temperature range of maximum 29.50$36.50^{\circ} \mathrm{C}$ and minimum $11.07-26.21^{\circ} \mathrm{C}$ and RH $67.00-84.57 \%$ and total rainfall $2.17 \mathrm{~mm}$ during crop growth period. The crop was grown during the Kharif, 2015 following the recommended agronomic practices in a Randomized Block Design (RBD) with three replications.

The observations on major insect pests were recorded on 5 randomly selected plants of the crop in a standard week from sowing to till the availability of insects or harvesting of the crop. The sap feeders were recorded by counting number of nymphs and adults per plant per cage during early morning hours 7.00 a.m- 8.00a.m. Larvae of defoliators and coccinellid larvae/adults were recorded by shaking the plants on polythene sheet of one square meter area in each plot (Yadav et al., 2015). Meteorological data were collected from the Department of Meteorology of this University.

\section{Results and Discussion}

\section{White fly, Bemisia tabaci (Genn.)}

The first appearance of whitefly population $1.80 /$ plant / cage was noticed in the 35th standard week. The whitefly population was observed in the third week of August and continued up to last week of October. The population followed gradually increase and attain peak population 18.50/cage/plant during $39^{\text {th }}$ standard week (Table 1 ) at $35.57-22.35^{\circ} \mathrm{C}$ temperature and R.H $72.00 \%$. The population of whitefly showed non-significant positive correlation with temperature (maximum and minimum) and rainfall and showed nonsignificant negative correlation with relative humidity (Table 2). These findings are in accordance with the findings of Singh and Kumar (2011), Yadav et al., (2015) and Kumar and Singh (2016).

\section{Jassid, Empoasca kerri Pruthi}

Empoasca kerri is an important pest of the blackgram crop. The pest marked its first appearance during $35^{\text {th }}$ standard week with initial mean population of6.00 jassids/cage/plant followed a gradual increase and attained peak population of 36.80 jassids/cage during $39^{\text {th }}$ standard week (Table 1) at $35.57-22.35^{\circ} \mathrm{C}$ temperature and R.H $72.00 \%$. The population of jassid showed nonsignificant positive correlation with temperature (maximum and minimum) and rainfall and showed non-significant negative correlation with relative humidity(Table 2). These findings are in accordance with the findings of Nayak et al., (2004), Singh and Kumar (2011) and Yadav et al., (2015). 


\section{Tobacco caterpillar, Spodoptera litura (F.)}

S. litura larval population 3.20/plant was first noticed during $37^{\text {th }}$ standard week. The larval population followed gradually increase and attain peak population 10.40 larvae/ plant during $39^{\text {th }}$ standard week (Table 1) at 35.57$22.35^{\circ} \mathrm{C}$ temperature and R.H $72.00 \%$.The population of $S$. litura showed non-significant positive correlation with maximum temperature while non-significant negative correlation with minimum temperature and rainfall. The population showed significant negative correlation with relative humidity (Table 2). These findings are in accordance with the findings of Yadav et al., (2015).

\section{Bihar hairy caterpillar, Spilosoma obliqua Walker}

The pest marked its first appearance during $35^{\text {th }}$ standard week with initial mean population of 2.20larvae/plant followed a gradual increase and attained peak population of 12.60 larvae/plant during $39^{\text {th }}$ standard week (Table 1) at $35.57-22.35^{\circ} \mathrm{C}$ temperature and
R.H $72.00 \%$. The population of S. obliqua showed non-significant positive correlation with temperature (maximum and minimum) and rainfall and non-significant negative correlation with relative humidity (Table 2). These findings are in accordance with the findings of Kumar et al., (1998) and Yadav et al., (2015).

\section{Coccinellid, Coccinella septempunctata $\mathbf{L}$.}

The incidence of adult beetle/plant was first observed during $39^{\text {th }}$ standard week and it remained present on the crop up to 43th standard week (one week before harvest). The maximum population 2.00 was found in the $41^{\text {th }}$ standard week at temperature 33.92 $20.35^{\circ} \mathrm{C}$ and R.H $67.00 \%$. The population of C. septempunctata showed non-significant positive correlation with maximum temperature where as non-significant negative correlation with minimum temperature and rainfall and significant negative correlation with relative humidity (Table 2). These findings are in accordance with the findings of Yadav et al., (2015) and Patel et al., (2010).

Table.1 Seasonal incidence of major insect pests on black gram Vigna mungo (Linn.) during Kharif 2015

\begin{tabular}{|c|c|c|c|c|c|c|}
\hline \multirow{2}{*}{$\begin{array}{l}\text { Dates of observation } \\
\text { (Standard Week) }\end{array}$} & \multicolumn{6}{|c|}{ Average insect population/plant } \\
\hline & $\begin{array}{c}\text { B. tabaci } \\
\text { (/cage/plant) }\end{array}$ & $\begin{array}{c}\text { E. kerri } \\
\text { (/cage/ } \\
\text { plant) }\end{array}$ & $\begin{array}{l}\text { S. litura } \\
\text { (per } \\
\text { plant) }\end{array}$ & $\begin{array}{c}\text { S. obliqua } \\
\text { (per } \\
\text { plant) }\end{array}$ & $\begin{array}{c}C . \\
\text { septumpuctata } \\
\text { (per plant) }\end{array}$ & $\begin{array}{c}\text { C. sexmaculata } \\
\text { (per plant) }\end{array}$ \\
\hline 35 (27 Aug-02 Sep) & 1.80 & 6.00 & 0.00 & 2.20 & 0.00 & 0.00 \\
\hline 36 (03-09 Sep) & 6.90 & 18.80 & 0.00 & 4.60 & 0.00 & 0.00 \\
\hline 37 (10-16 Sep) & 9.40 & 28.20 & 3.20 & 10.00 & 0.00 & 0.00 \\
\hline 38 (17-23 Sep) & 9.20 & 22.00 & 4.00 & 8.80 & 0.00 & 0.00 \\
\hline 39 (24-30 Sep) & 18.50 & 36.80 & 10.40 & 12.60 & 1.00 & 1.20 \\
\hline 40 (01-07 Oct) & 16.10 & 28.00 & 9.80 & 10.00 & 1.80 & 0.95 \\
\hline 41 (08-14 Oct) & 12.50 & 30.20 & 10.00 & 4.20 & 2.00 & 0.80 \\
\hline 42 (15-21 Oct) & 7.00 & 22.00 & 9.20 & 2.80 & 1.80 & 0.70 \\
\hline 43 (22-28 Oct) & 2.10 & 8.00 & 2.00 & 2.20 & 1.00 & 0.40 \\
\hline 44 (29-04 Nov) & 1.20 & 4.00 & 0.00 & 1.60 & 0.00 & 0.10 \\
\hline
\end{tabular}


Table.2 Correlation coefficient (r) between weather parameters and population of major insect pests of black gram and coccinellids

\begin{tabular}{|c|l|l|l|l|l|}
\hline SI.No. & Insect & Max. Temp. & Min. Temp. & R.H. (\%) & Rain fall \\
\hline $\mathbf{1}$ & B. tabaci & $0.506 \mathrm{NS}$ & $0.281 \mathrm{NS}$ & $-0.470 \mathrm{NS}$ & $0.043 \mathrm{NS}$ \\
\hline $\mathbf{2}$ & E. kerri & $0.556 \mathrm{NS}$ & $0.360 \mathrm{NS}$ & $-0.437 \mathrm{NS}$ & $0.50 \mathrm{NS}$ \\
\hline $\mathbf{3}$ & S. litura & $0.282 \mathrm{NS}$ & $-0.056 \mathrm{NS}$ & $-0.733^{*}$ & $-0.067 \mathrm{NS}$ \\
\hline $\mathbf{4}$ & S. obliqua & $0.573 \mathrm{NS}$ & $0.478 \mathrm{NS}$ & $-0.094 \mathrm{NS}$ & $0.252 \mathrm{NS}$ \\
\hline $\mathbf{5}$ & C. septempunctata & $0.111 \mathrm{NS}$ & $-0.359 \mathrm{NS}$ & $-0.914^{*}$ & $-0.309 \mathrm{NS}$ \\
\hline $\mathbf{6}$ & C. sexmaculata & $0.134 \mathrm{NS}$ & $-0.280 \mathrm{NS}$ & $-0.807^{*}$ & $-0.316 \mathrm{NS}$ \\
\hline
\end{tabular}

$* \mathrm{P}<0.05$ (significant)

Fig.1 Seasonal incidence of major insect-pests of black gram, during kharif, 2015 Tobacco caterpillar, Spodoptera litura (F.)

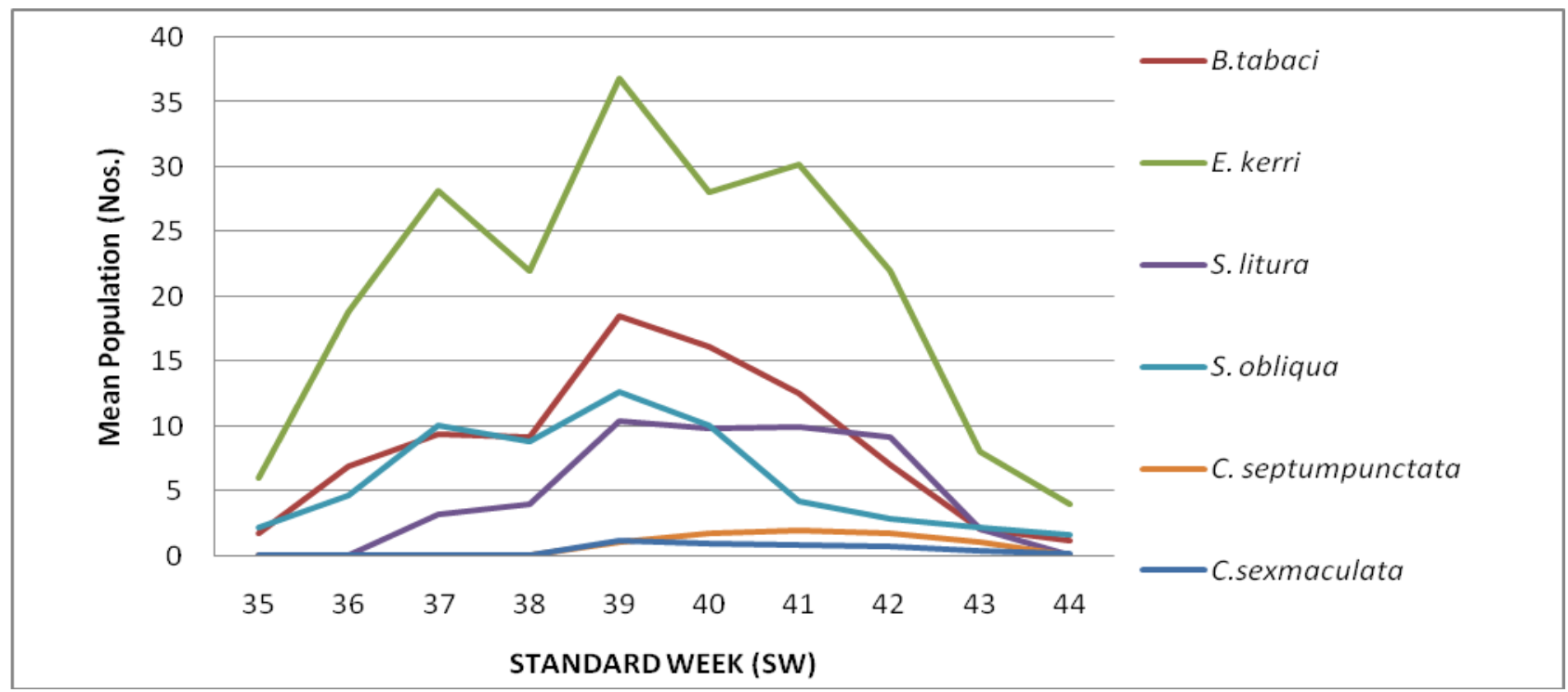

Coccinellid, Cheilomenes sexmaculata (F.)

The incidence of adult beetle/plant was first observed during $39^{\text {th }}$ standard week and it remained present on the crop up to $44^{\text {th }}$ standard week (till harvest). The maximum population 1.20 was found in the $39^{\text {th }}$ standard week at temperature $33.92-20.35^{\circ} \mathrm{C}$ and R.H is $72.00 \%$. The population of $C$. sexmaculata showed non-significant positive correlation with maximum temperature where as nonsignificant negative correlation with minimum temperature and rainfall and significant negative correlation with relative humidity (Table 2). These findings are in accordance with the findings of Yadav et al., (2015) and Patel et al., (2010).

In conclusion, the study about seasonal incidence of insect pests is one of the most important objectives of pest management. This provides the data of seasonal fluctuation and peak activity of insect pests. Correlation study of insect-pests population with weather parameters also provides information about weather influence on insect pest population. The information collected in this study is very useful in insect pest management. 


\section{References}

Ali, M. and Gupta, S. (2012). Carrying capacity of Indian agriculture pulse crops. Current Science, 102: 874- 88.

Anonymous, (2016). Directorate of Economics and Statistics. Department of Agriculture and Cooperation.

Khajuria, S., Rai, A.K., Kumar, K.L.R., Jadav J.K. (2015). Evaluation of integrated pest management (IPM) module against sucking-pest of black gram under semi-arid conditions. Insect Environment, 20(4): 126-132.

Kumar, V.; Manglik, V.P. and Bhattacharya, A.K. (1998). Estimation of population density of some insect pests of soybean.J. of Insect Sci. 11(1): 14-18.

Kumar M. and Singh P.S. (2016). Population dynamics of major insect pest of blackgram [Vigna Mungo (L.) Hepper] in relation to weather parameters. International Journal of Agriculture, Environment and Biotechnology. 9(4): 673-677.

Nayak, S.K.; Ram Ujagir and Chhibber, R.C. (2004). Effect of abiotic factors on the insect population build up on blackgram,Vigna mungo L. crop. Shashpa.11(1): 31-36.

Patel, S.K.; Patel, B.H.; Korat, D.M. and Dabhi, M.R. (2010). Seasonal incidence of major insect pests of cowpea, Vigna unguiculata (Linn.) Walpers in relation to weather parameters. Karnataka J. Agric. Sci. 23(3): 497-499.

Rabindra, R. J., Ballali, C. R. and Ramanujan, B. (2004). Biological options for insect pests and nematode management in pulses. Kalyani Publishers, New Delhi, India, p. 487.

Singh, S. S. 2004. Crop Management, 3rd Ed. Kalyani Publishers, New Delhi, p. 574.

Singh, D.C. and Kumar, P. (2011). Population dynamics and management of Bemisia tabaci in urdbean. Ann. Pl. Protec. Sci.19 (1): 203-260

Yadav, S.K., Meena Agnihotri and Bisht, R.S. (2015). Seasonal incidence of insectpests of blackgram,Vigna mungo (Linn.) and its correlation with abiotic factors. Agricuture Sciences Digest 35(2): 146-148.

\section{How to cite this article:}

Mun Mun Mohapatra, D.C. Singh, P.K. Gupta, U. Chandra, B. Patro and S.D. Mohapatra. 2018. Seasonal Incidence of Major Insect-Pests on Blackgram, Vigna mungo (Linn.) and Its Correlation with Weather Parameters. Int.J.Curr.Microbiol.App.Sci. 7(06): 3886-3890.

doi: https://doi.org/10.20546/ijcmas.2018.706.458 